\title{
Quercetin Suppresses Bone Resorption by Inhibiting the Differentiation and Activation of Osteoclasts
}

\author{
Je-Tae Woo, ${ }^{*}, a$ Hiroshi Nakagawa, ${ }^{b}$ Michitaka Notoya, ${ }^{b}$ Takayuki Yonezawa, ${ }^{a}$ Nobuyuki Udagawa, ${ }^{c}$ \\ In-Seon Lee, ${ }^{d}$ Motoko Ohnishi ${ }^{a}$ Hiromi Hagiwara, ${ }^{b}$ and Kazuo NAGAI ${ }^{a}$ \\ ${ }^{a}$ Department of Biological Chemistry, Chubu University; 1200 Matsumoto, Kasugai, Aichi 487-8501, Japan: ${ }^{b}$ Department \\ of Biological Sciences, Tokyo Institute of Technology; 4259 Nagatsuta-cho, Midori-ku, Yokohama 226-8501, Japan: \\ ${ }^{c}$ Department of Biochemistry, School of Dentistry, Matsumoto Dental University; 1780 Hirookagoubara, Shiojiri, Nagano \\ 397-0781, Japan: and In-Seon, Lee Center for Traditional Microorganism Resources, Keimyung University; Taegu \\ Korea. Received September 4, 2003; accepted December 16, 2003
}

\begin{abstract}
Although quercetin has suppressed bone resorption in several animal studies, its target cells and the mechanism of its action related to bone resorption has not been fully elucidated. We investigated the effect of quercetin on the differentiation and activation of osteoclasts. We used cocultures of mouse spleen cells and ST2 cells, and cultures of osteoclast progenitor cells \{M-CSF-dependent (MD) cells from mouse bone marrow and murine monocytic RAW 264 (RAW) cells\}. Quercetin dose-dependently inhibited osteoclast-like (OCL) cell formation at 2-5 $\mu_{\mathrm{M}}$ concentration in both the coculture and MD cell culture. Quercetin inhibited the increase of tartrate-resistant acid phosphatase (TRAP) activity of mononuclear preosteoclasts (pOCs) induced by receptor activator of nuclear factor- $\kappa B(N F-\kappa B)$ ligand (RANKL) in both MD and RAW cell cultures. Quercetin reversely induced the disruption of actin rings in OCLs. Quercetin also suppressed both pit formation induced by osteoclasts on dentine slices and PTH-stimulated ${ }^{45} \mathrm{Ca}$ release in mouse long bone cultures. These results suggest that osteoclast progenitors as well as mature osteoclasts, are quercetin's target cells in relation to bone resorption, and that quercetin's suppressive effect on bone resorption results from both its inhibitory effect on the differentiation of osteoclast progenitor cells into pOCs and from its disruptive effect on actin rings in mature osteoclasts.
\end{abstract}

Key words quercetin; osteoclast; bone resorption; osteoclast activation; osteoclast differentiation

Osteoclasts are multinucleated cells that differentiate from hematopoietic precursors ${ }^{1)}$ and possess characteristics to resorb mineralized bone. Osteoclast-like multinucleated cells (OCLs) can be differentiated in vitro from cocultures of mouse bone marrow cells and calvarial osteoblastic cells by treatment with osteotropic factors such as $1 \alpha, 25$-dihydroxyvitamin $\mathrm{D}_{3}$, prostaglandin $\mathrm{E}_{2}$, interleukin-1 (IL-1) or parathyroid hormone. ${ }^{2,3)}$ Osteoblasts or stromal cells are the target cells for these factors in bone. Recently, an essential factor provided by osteoblasts or stromal cells has been identified and named osteoclast differentiation factor (ODF)/osteoprotegerin ligand (OPGL)/tumor necrosis factor-related activation-induced cytokine (TRANCE)/receptor activator of nuclear factor- $\kappa \mathrm{B}(\mathrm{NF}-\kappa \mathrm{B})$ ligand (RANKL). ${ }^{4,5}$ It has been shown that RANKL induces OCL formation in cultures of bone marrow cells in the presence of M-CSF without requiring osteoblasts or stromal cells. ${ }^{6}$ ) RAW cells are also known to differentiate into osteoclasts in the presence of RANKL. ${ }^{6}$

Several vegetables (onion, parsley, etc.) have attracted attention for their potential beneficial effects for the prevention of bone diseases such as postmenopausal osteoporosis. ${ }^{7)}$ Among them, onions have been shown to have the strongest properties to regulate bone metabolism ${ }^{7)}$; rats fed onions increased their bone mass. ${ }^{8)}$ Onion also inhibits bone resorption stimulated in ovariectomized rat, ${ }^{9,10)}$ and an extract from onion is known to prevent tibial cortical and cancellous bone loss induced by a combination of low protein intake and diet-mediated mild hyperparathyroidism in rats. ${ }^{11)}$ Rutin (quercetin-3-O-glucose rhamnose) (Fig. 1) has recently been reported to inhibit ovariectomy-stimulated bone resorption in rats. ${ }^{12)}$ These facts taken together suggest that rutin is one of the principal components of onions that effectively facilitate bone resorption, and that its inhibitory effect on bone loss could in part be responsible for its effects on increasing bone mass.

Quercetin (Fig. 1) is the major representative of the flavonoid subclass of flavonols commonly found in fruits and vegetables, ${ }^{13,14)}$ and is also abundant in onion extracts $(200$ $600 \mathrm{mg}$ quercetin $/ \mathrm{kg}$ onion) and primarily in the form of glycoside (rutin). ${ }^{14)}$ Dietary glycosides like rutin are thought to be converted into aglycone (like quercetin) in the large intestine by the glycosidase activity of intestinal bacteria. ${ }^{15)}$ While these facts suggest that quercetin inhibits bone resorption in animals, its target cells for bone resorption and its mode of action has not been fully elucidated. We investigated the effects of quercetin on the differentiation and activation of osteoclasts, and on bone resorption in cultures. We show here that quercetin inhibits pOC formation induced by sRANKL<smiles>O=c1c(O)c(-c2ccc(O)c(O)c2)oc2cc(O)cc(O)c12</smiles>

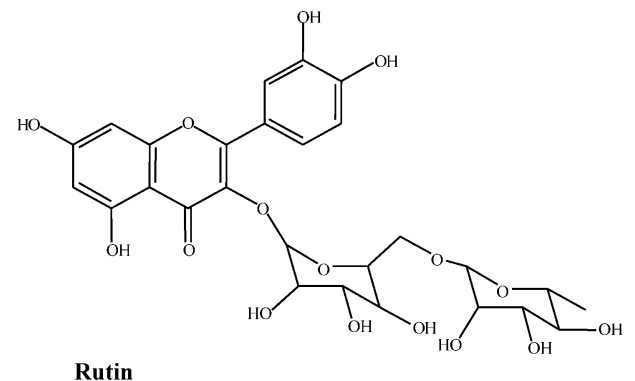

Fig. 1. Structure of Quercetin and Rutin (Quercetin-3-O-B-rutinoside) 
in cultures of mouse marrow-derived MD cells, and that it also inhibits bone resorption in organ cultures. Our results suggest that the inhibitory effect of quercetin both on differentiation and on actin ring formation in OCLs causes a suppressive effect on bone resorption.

\section{MATERIALS AND METHODS}

Materials Six- to nine-week-old male Std.ddY mice were purchased from Japan SLC Co. (Hamamatsu, Japan). Quercetin (dissolved in dimethylsulfoxide or ethanol; final concentrations of DMSO and ethanol were $0.05 \%$ and less than $1 \%$, respectively, and these concentrations did not affect the formation of osteoclast-like cells) and 1 $\alpha, 25$-dihydroxyvitamin $\mathrm{D}_{3}\left[1 \alpha, 25(\mathrm{OH})_{2} \mathrm{D}_{3}\right]$ were from Wako Pure Chemical Industries, Ltd. (Osaka, Japan). Fast violet LB salt and naphthol AS-MX phosphate were purchased from Sigma Chemical Co. (St. Louis, MO, U.S.A.). Recombinant murine MCSF and recombinant human RANKL (sRANKL) were from R\&D Systems (Minneapolis, MN, U.S.A.) and Pepro Tech EC. Ltd. (London, England), respectively. PD 98059 was from Calbiochem (San Diego, CA, U.S.A.). ${ }^{45} \mathrm{CaCl}_{2}$ was obtained from Amersham Pharmacia Biotech (Buckinghamshire, U.K.). All other reagents were obtained from Sigma (St. Louis, MO, U.S.A.) unless otherwise stated.

Formation of Osteoclast-Like Cells from Coculture Spleen cells were collected from the splenic tissues of six- to nine-week-old male ddY mice. Erythrocytes contaminating the spleen cell fraction were eliminated by adding $0.83 \%$ ammonium chloride in $10 \mathrm{~mm}$ Tris/ $\mathrm{HCl}(\mathrm{pH} 7.4)$ to the cell pellet. Mouse clonal stromal cells from bone marrow (ST2 cells) were supplied by the RIKEN Cell Bank (Tsukuba, Japan). ST2 cells were cocultured $\left(2 \times 10^{4}\right.$ cells/well $)$ with mouse spleen cells $\left(1 \times 10^{5}\right.$ cells/well $)$ in $\alpha$-MEM that contained $10 \%$ fetal bovine serum (FBS) and $10^{-8} \mathrm{M}$ $1 \alpha, 25(\mathrm{OH})_{2}$ vitamin $\mathrm{D}_{3}$ in 48 -well plates $\left(0.98 \mathrm{~cm}^{2} /\right.$ well). The cultures were maintained at $37^{\circ} \mathrm{C}$ in a humidified atmosphere of $5 \% \mathrm{CO}_{2}$ in air. Fresh medium and quercetin were supplied at 2-d intervals. The animal protocols and procedures were approved by the Institutional Animal Care and Use Committee of Chubu University.

Formation of Osteoclast-Like Cells from MD and RAW Cells Bone marrow cells were isolated from six- to nineweek-old male ddY mice as described previously. ${ }^{16)}$ Tibia and femora were aseptically removed and dissected free of adherent soft tissue. The bone ends were cut off and the marrow was forced out into a petri dish containing $\alpha$ $\mathrm{MEM}+10 \% \mathrm{FBS}$. The marrow suspension was filtered with a fine mesh (about $100 \mu \mathrm{m}$ ) sieve to remove bone particles, then carefully agitated with a plastic Pasteur pipette to obtain a single-cell suspension. The bone marrow cells were washed twice, resuspended in $\alpha$-MEM $+10 \%$ FBS, and incubated for $24 \mathrm{~h}$ in M-CSF $(5 \mathrm{ng} / \mathrm{ml})$ at a density of $1 \times 10^{6}$ cells $/ \mathrm{ml}$ in $100 \mathrm{~mm}$ dishes. After $24 \mathrm{~h}$, non-adherent cells were harvested, washed, and resuspended $\left(1 \times 10^{6}\right.$ cells $\left./ \mathrm{ml}\right)$ in $\alpha$ $\mathrm{MEM}+10 \%$ FBS. These non-adherent cells were used as MD cells for osteoclast formation experiments. MD cells $\left(1 \times 10^{6} / \mathrm{ml}\right)$ were added $(100 \mu \mathrm{l} /$ well $)$ to $96-$ well plates. After $24 \mathrm{~h}$, an additional $100 \mu \mathrm{l}$ of $\alpha$-MEM $+10 \%$ FBS containing cytokines (M-CSF or sRANKL) was added to each well. The cells were then cultured for $1-3 \mathrm{~d}$. RAW cells, which were supplied by the RIKEN Cell Bank (Tsukuba, Japan), were seeded to a 96 -well plate $\left(3 \times 10^{3}\right.$ cells/well). After $24 \mathrm{~h}$, an additional $100 \mu \mathrm{l}$ of medium containing sRANKL was added to each well. Osteoclast formation was evaluated by measuring TRAP activity in the fixed cells and by counting the number of TRAP-stained cells.

Localization of Tartrate-Resistant Acid Phosphatase (TRAP) After cell cultures, adherent cells were fixed in $10 \%$ formaldehyde for $10 \mathrm{~min}$ and then in a mixture of ethanol and acetone $(1: 1, \mathrm{v} / \mathrm{v})$ for $1 \mathrm{~min}$. Then they were stained for TRAP activity as previously described. ${ }^{17)}$ TRAPpositive mononuclear cells and TRAP-positive multinucleated cells (three or more nuclei) were counted under a microscope (IX70; Olympus).

TRAP Activity of the Culture Cells The cells were fixed with $10 \%$ formalin for $10 \mathrm{~min}$ and $95 \%$ ethanol for $1 \mathrm{~min}$, and then dried. To measure TRAP activity, $100 \mu \mathrm{l}$ citrate buffer $(50 \mathrm{~mm}, \mathrm{pH} 4.6)$ containing $10 \mathrm{~mm}$ tartrate and $5 \mathrm{~mm} p$-nitrophenylphosphate was added to the dried cellcontaining wells. After incubation for $20-30 \mathrm{~min}$, the enzyme reaction mixtures in the wells were transferred into another 96 well plate containing $100 \mu \mathrm{l}$ of $0.1 \mathrm{~N}-\mathrm{NaOH}$. Absorption was measured at $410 \mathrm{~nm}$ with a microplate reader (Molecular Devices).

Viability Assay Cell viability was evaluated using a 3[4,5-dimethylthiazol-2-yl]-2,5-diphenyl tetrazolium bromide (MTT) assay. MD cells or RAW cells $\left(1 \times 10^{4}\right.$ cells/well; 96well plates) were cultured in the presence of quercetin for $24 \mathrm{~h}$. After culture, cells were treated with MTT (a final conc. of $20 \mu \mathrm{g} / \mathrm{ml}$ ) for $2 \mathrm{~h}$, then precipitated dye was solubilized into dimethylsulfoxide, and the absorbance at $570 \mathrm{~nm}$ was measured.

Actin Ring Staining Actin rings of OCLs were detected by staining actin filaments with rhodamine-conjugated phalloidin. OCLs (about 200 cells/well) were formed from RAW cell cultures in the presence of sRANKL and PD 98059 $(20 \mu \mathrm{M})(\mathrm{PD} 98059$ is known to increase TRAP- $(+)$ cell formation induced by sRANKL in RAW 264.7 cell culture ${ }^{18)}$; thus, we used PD98059 to rapidly prepare a high number of mature OCLs with actin rings), and treated with quercetin for $24 \mathrm{~h}$. At the end of incubation, OCLs were stained for TRAP activity for $30 \mathrm{~min}$ at room temperature. TRAP-positive OCLs were stained with rhodamine-conjugated phalloidin in the dark, and washed with cold phosphate-buffered saline (PBS). The distribution of actin rings of OCLs was visualized and detected under a fluorescence microscope.

Assay for Pit Formation The pit-forming activity of OCLs was determined by using a previously described modified method. ${ }^{19)}$ Briefly, crude OCL preparations, collected from ocultures of mouse spleen cells and ST2 cells on culture dishes precoated with $0.2 \%$ collagen gel matrix, were placed on 96-well plates containing dentine slices $(4 \mathrm{~mm}$ in diameter) in the presence of quercetin for $24 \mathrm{~h}$. After $24 \mathrm{~h}$ incubation, dentine slices were ultrasonicated in $1 \mathrm{M}$ aqueous $\mathrm{NH}_{4} \mathrm{OH}$ to remove adherent cells. Resorption pits on the slice were stained with Mayer's hematoxylin solution. The number of pits was counted by microscopic observation.

Assay for ${ }^{45} \mathrm{Ca}$ Release from Long-Bone in Organ Culture System Pregnant ddY mice were injected sc with $25 \mu \mathrm{Ci}$ of ${ }^{45} \mathrm{Ca}$ (Amersham Pharmacia Biotech, Buckinghamshire, U.K.) on day 16 of gestation. Twenty-four hours 
after injection, radii and ulnae shafts were dissected from the fetuses, cleaned free of surrounding muscle and fibrous tissues, and precultured in serum- or BSA-free BGJb medium (Life Technologies, Grand Island, NY, U.S.A.). After $48 \mathrm{~h}$ preincubation, the bones were transferred into $0.5 \mathrm{ml}$ BGJb medium containing $0.2 \%$ BSA and incubated for $72 \mathrm{~h}$ with or without quercetin in the presence of PTH $\left(10^{-7} \mathrm{M}\right)$. At the end of the culture period, the bones were extracted in $0.1 \mathrm{~N}$ $\mathrm{HCl}$. Radioactivity in media and bone extracts was determined by liquid scintillation spectrophotometry. Bone-resorbing activity was expressed as the percentage of the incorporated ${ }^{45} \mathrm{Ca}$ that was released into the medium.

\section{RESULTS}

Quercetin Inhibits OCL Formation First, for OCL formation we used a coculture system of mouse spleen and ST2 cells. When the coculture was treated with quercetin for $8 \mathrm{~d}$ in the presence of $1 \alpha, 25(\mathrm{OH})_{2} \mathrm{D}_{3}$, OCL formation was inhibited (Figs. 2A, B-E). The inhibitory effect of quercetin was in a dose-dependent manner. The quercetin concentration producing 50\% inhibition was approximately $3 \mu \mathrm{M}$ (Fig. 1A), and quercetin $5 \mu \mathrm{M}$ inhibited OCL formation by more than $90 \%$ (Figs. 2A, B). To determine the effects of quercetin on
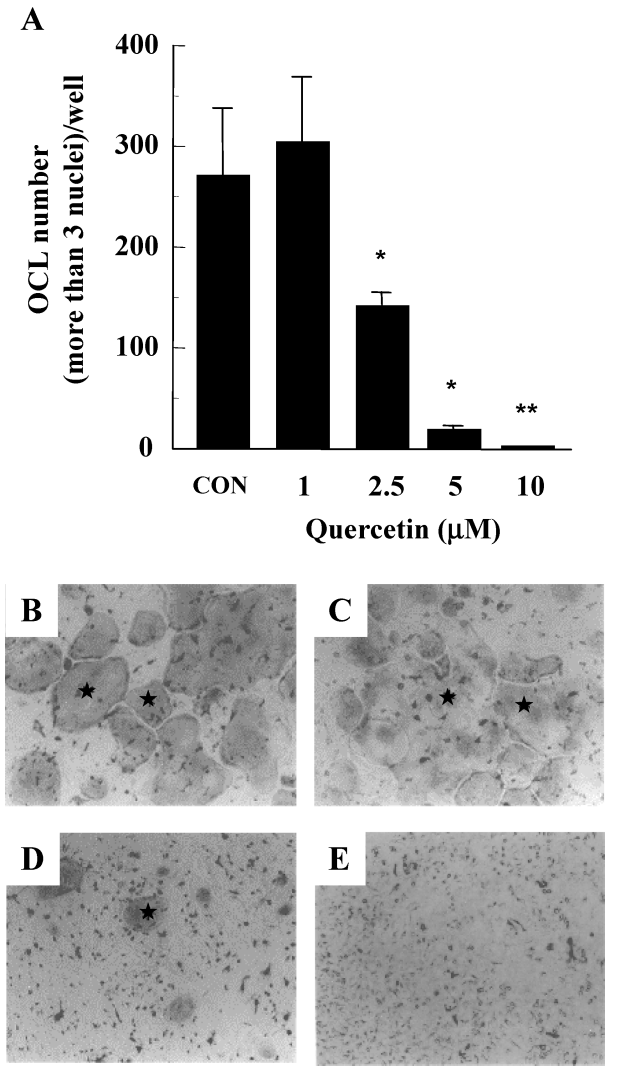

Fig. 2. The Effect of Quercetin on the Formation of TRAP-Positive Osteoclast-Like Cells

Mouse spleen cells were cocultured with ST2 cells in 48-well plates for $8 \mathrm{~d}$ in $\alpha$ MEM that contained $10 \%$ fetal bovine serum and $10^{-8} \mathrm{M} 1 \alpha, 25(\mathrm{OH})_{2} \mathrm{D}_{3}$ with, and without quercetin at the indicated concentrations. Control cultures were supplemented with $0.05 \%$ dimethylsulfoxide. Fresh mediums with and without quercetin were supplied at 3 -d intervals. The cells were stained for TRAP activity, and TRAP- $(+)$ OCLs were counted under a microscope (A). Data are means \pm S.E.of results from four determinations. *, $p<0.01 v s$. control; **, $p<0.001 v s$. control. (B-E) Photographs of TRAP (+) OCLs formed in the absence (B) or the presence of quercetin of $1 \mu \mathrm{M}(\mathrm{C}), 5 \mu \mathrm{M}$ (D) and $10 \mu \mathrm{M}(\mathrm{E})$. Asterisks indicate OCLs (B, C, D).
OCL formation from osteoclast progenitor cells in the absence of osteoblasts, we used MD cells derived from bone marrow. As shown in Fig. 3, sRANKL dramatically induced OCL formation in MD cell cultures for $4 \mathrm{~d}$ (Fig. 3A). Quercetin inhibited OCL formation induced by sRANKL at $1-4 \mu \mathrm{M}$ of concentration in a dose-dependent manner, and $4 \mu_{\mathrm{M}}$ quercetin inhibited OCL formation by about $90 \%$. The $\mathrm{IC}_{50}$ for the effects was approximately $1 \mu \mathrm{M}$ (Fig. 3A). However, as detected by MTT assay, MD cell viability was not affected by quercetin (Fig. 3B). These results suggest that quercetin directly acts on osteoclast progenitors, and then inhibits OCL formation.

Quercetin Inhibits TRAP Activity of pOC Cells Induced by sRANKL Next, we determined whether quercetin inhibits TRAP- $(+)$ preosteoclast $(\mathrm{pOC})$ formation from osteoclast progenitors. sRANKL stimulated TRAP activity in the cultures of both MD cells (Fig. 3A) and RAW cells (Fig. 4). TRAP- $(+)$ pOC cells were formed in the cultures of both MD cells (within $2 \mathrm{~d}$ treatment of sRANKL)
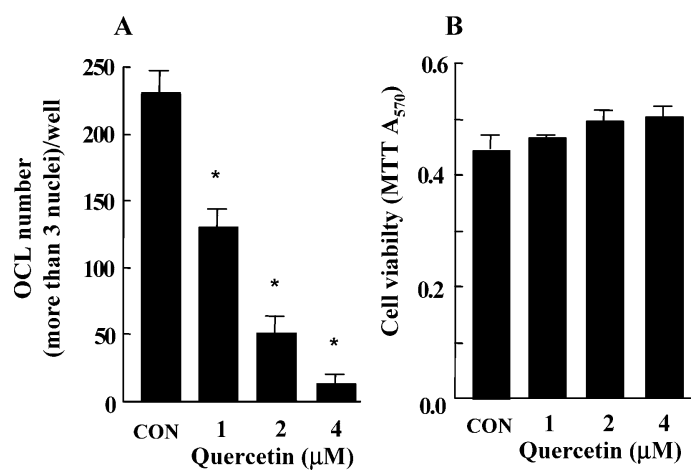

Fig. 3. The Effect of Quercetin on OCL Formation (A) and Cell Viability (B) in MD Cell Cultures

MD cells $\left(1 \times 10^{5}\right.$ cells/well $)$ in 96-well plates derived from bone marrow cells were cultured with and without quercetin in the presence or absence of RANKL $(100 \mathrm{ng} / \mathrm{ml})$. Control cultures were supplemented with $0.5 \%$ ethanol. After culture for $4 \mathrm{~d}$, the cells were stained for TRAP activity, and OCLs were counted under a microscope (A). Cell viability was determined by MTT assay after culture (B). Data are means \pm S.E. of results from three determinations. $*, p<0.01 v s$. control.

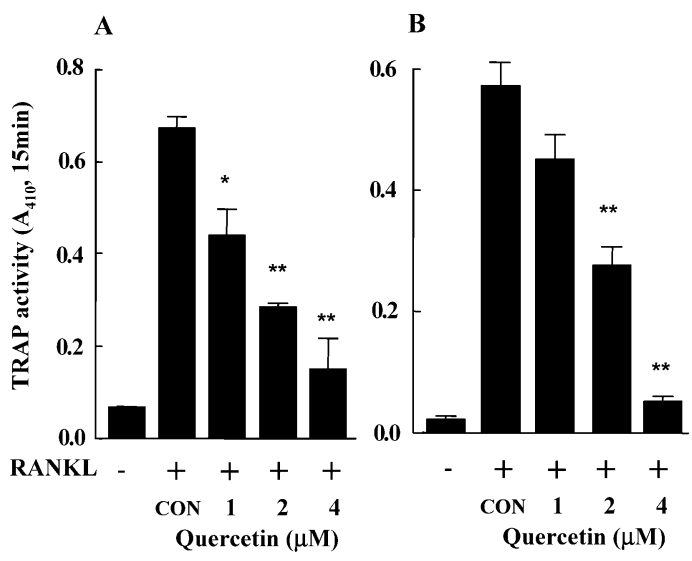

Fig. 4. The Effect of Quercetin on TRAP Activity Induced by RANKL in Both MD (A) and RAW Cell (B) Cultures

MD cells $\left(1 \times 10^{5}\right.$ cells/well $)$ in 96-well plates were cultured with or without quercetin in the presence or absence of RANKL $(100 \mathrm{ng} / \mathrm{ml})$ for $2 \mathrm{~d}$. RAW cells (3000 cells/well) in 96-well plates were cultured with and without quercetin in the presence of $100 \mathrm{ng} / \mathrm{ml}$ RANKL for $3 \mathrm{~d}$. Control cultures were supplemented with $0.5 \%$ ethanol. After culture, the cells were fixed and their TRAP activities were determined. Data are means \pm S.E. of results from three determinations. $*, p<0.05 v s$. control; $* *$, $p<0.01$ vs. control. 
and RAW cells (within $3 \mathrm{~d}$ treatment of sRANKL), but no OCLs were formed in a two-day culture of MD cells or in three-day culture of RAW cells. Quercetin inhibited an increase of sRANKL-induced TRAP activity of pOC cells in both cell cultures (Figs. 4A, B). The $\mathrm{IC}_{50}$ for the effects of quercetin on the MD and RAW cells was approximately 1.5 and $2 \mu \mathrm{M}$, respectively. The effect of quercetin on the TRAP activity of pOC cells was consistent with that on OCL formation in MD cells and coculture. Quercetin did not affect the cell viability of RAW cells at $4 \mu \mathrm{M}$ (data not shown), as judged from microscopic observation of the Dye-exclusion test using trypan blue. These results support the theory that quercetin acts directly on osteoclast progenitors.

Quercetin Induces the Disruption of Actin Rings in Mature Osteoclasts Actin ring formation in mature osteoclasts is essential to express bone resorption function. OCLs formed by the treatment of RAW cells with sRANKL readily form resorption pits on bone slices, ${ }^{6)}$ and PD 98059 stimulates OCL formation induced by sRANKL from RAW cells. ${ }^{18)}$ Therefore, we determined the effect of quercetin on the actin rings of mature OCLs, which were formed from RAW cells in the presence of sRANKL and PD 98059. Actin rings were visualized by staining actin with rhodamine-conjugated phalloidin. When OCLs with actin rings were treated with quercetin for $24 \mathrm{~h}$, the size was constricted and the actin rings were disrupted (Fig. 5). The disruptive effect of quercetin on actin rings was in a dose-dependent manner (Fig. 6B). The quercetin concentration producing 50\% disruption was approximately $5 \mu \mathrm{M}$, and when $10 \mu \mathrm{M}$ quercetin was used, only about $10 \%$ of OCLs having actin rings remained. However, TRAP activity and the cell viability of OCLs was not significantly changed by quercetin (Figs. $6 \mathrm{~A}, \mathrm{C})$, and as judged from nuclear staining with Hoechst 33258, apoptotic OCLs, in which actin rings were disrupted, were not observed in the treatment of quercetin $10 \mu \mathrm{M}$ for $12 \mathrm{~h}$ (data not shown). In addition, when quercetin was removed after $12 \mathrm{~h}$ treatment, the number of OCLs having actin rings was restored to $80 \%$ of the control cultures $(24 \mathrm{~h})$ (Fig. 6D).

Quercetin Inhibits Bone Resorption To investigate the inhibitory effect of quercetin on bone resorption, we used both the pit formation assay and an organ culture system. Quercetin inhibited pit formation on dentine slices. $5 \mu \mathrm{M}$ quercetin inhibited pit formation by about 40\% (Fig. 7A). The effect of quercetin on ${ }^{45} \mathrm{Ca}$ released from the bone into the medium was measured in organ cultures. PTH stimulated bone resorption in organ cultures, resulting in a release of previously-incorporated ${ }^{45} \mathrm{Ca}$. PTH-stimulated ${ }^{45} \mathrm{Ca}$ release was inhibited by quercetin in a dose-dependent manner (2$10 \mu \mathrm{M})$ (Fig. 7B), but basal ${ }^{45} \mathrm{Ca}$ release was not significantly affected (data not shown). The quercetin concentration producing $50 \%$ inhibition was approximately $5 \mu \mathrm{M}$. The suppressive effects of quercetin on bone resorption were correspondent to its disruptive effect on actin rings in OCLs.

\section{DISCUSSION}

Although quercetin is thought to inhibit bone resorption in animals, its target cells related to bone resorption and its mode of action have not been fully elucidated. We determined the effects of quercetin on the function and differentia-

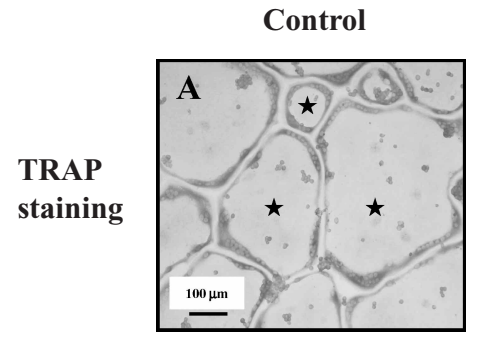

Quercetin $(10 \mu \mathrm{M})$

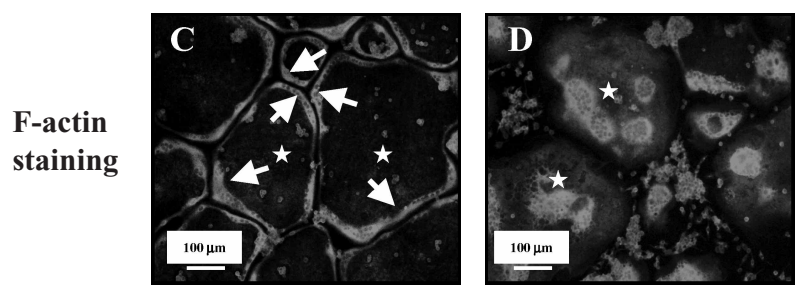

Fig. 5. The Effect of Quercetin on the Morphological Structure of Mature OCLs

RAW cells (12000 cells/well) in 96-well plates were cultured with PD98059 $(20 \mu \mathrm{M})$ in the presence of RANKL $(50 \mathrm{ng} / \mathrm{ml})$ for $4 \mathrm{~d}$. OCLs with actin rings were treated with quercetin $(10 \mu \mathrm{M})$ in the presence of RANKL $(50 \mathrm{ng} / \mathrm{ml})$ and PD98059 $(20 \mu \mathrm{M})$ for $24 \mathrm{~h}$. Control cultures were supplemented with $0.1 \%$ methanol. After culture, the cells were fixed and stained for TRAP, followed by rhodamine-conjugated phalloidin staining TRAP staining (A, B); actin staining (C, D). Asterisks and arrows indicate OCLs and actin rings, respectively.
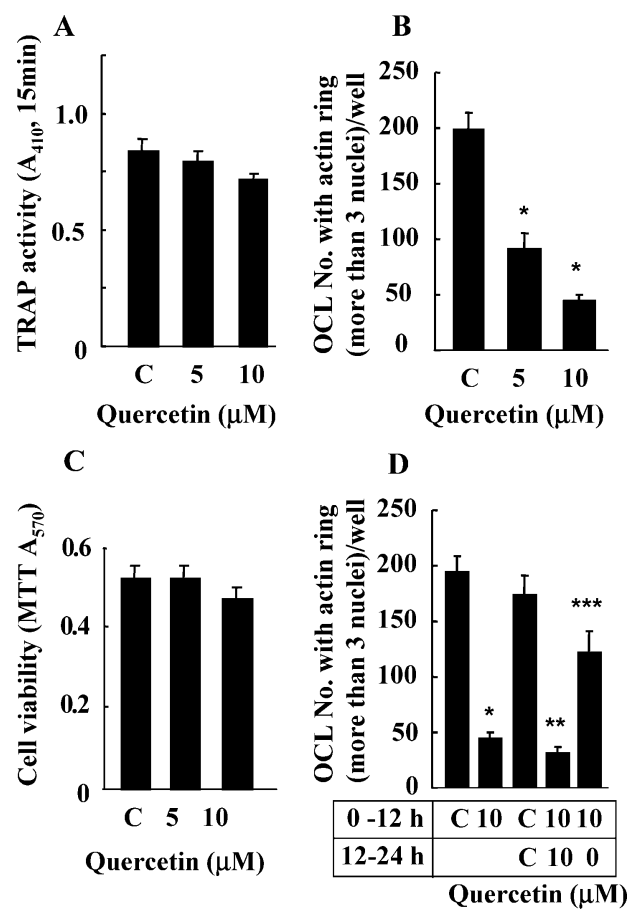

Fig. 6. The Effect of Quercetin on TRAP Activity and Survival of OCLs

RAW cells (12000 cells/well) in 96-well plates were cultured with PD98059 $(20 \mu \mathrm{M})$ in the presence of RANKL ( $100 \mathrm{ng} / \mathrm{ml})$ for $4 \mathrm{~d}$. (A, B, C) OCLs with actin rings were treated with and without quercetin for $12 \mathrm{~h}$ in the presence of RANKL $(50 \mathrm{ng} / \mathrm{ml})$ and PD98059 $(20 \mu \mathrm{M})$. (D) After OCLs with actin rings were treated with and without quercetin $(10 \mu \mathrm{M})$ for $12 \mathrm{~h}$ in the presence of RANKL $(50 \mathrm{ng} / \mathrm{ml})$ and PD98059 $(20 \mu \mathrm{M})$, quercetin $(10 \mu \mathrm{M})$ was washed out, and then OCLs were cultured in fresh medium with and without quercetin $(10 \mu \mathrm{M})$ for an additional $12 \mathrm{~h}$. Control cultures were supplemented with $0.5 \%$ ethanol. After cultures, the cells were fixed, and examined for TRAP activity and stained for TRAP, followed by rhodamine-conjugated phalloidin staining. TRAP- $(+)$ OCLs were counted under a microscope. Cell viability was determined by MTT assay after culture (C). TRAP activity (A); OCL number (B); cell viability (C); reversibility of quercetin effect (D). Data are means \pm S.E. of results from three determinations. $*, p<0.01 v s$. control $(12 \mathrm{~h}) ; * *, p<0.01 v s$. control $(24 \mathrm{~h}) ; * * *, p<0.01 v s$. quercetin-treated group (24h). 

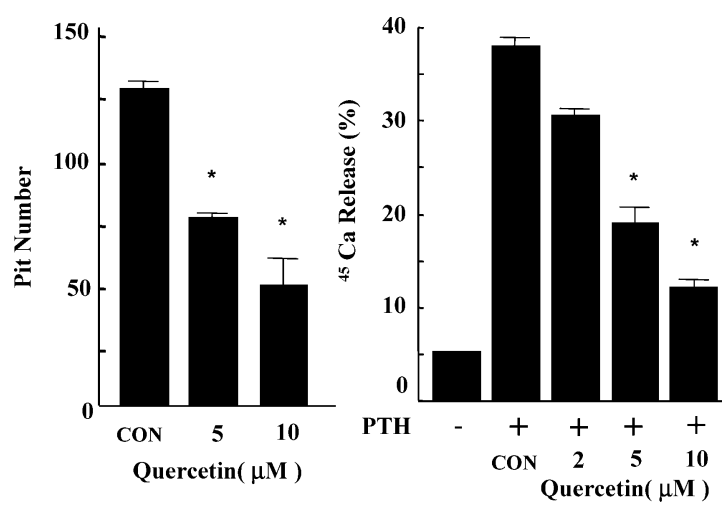

Fig. 7. The Effect of Quercetin on Bone Resorption in Both Pit Assay and Organ Cultures

(A) OCLs collected from cocultures were cultured on dentine slices in the presence of quercetin for $24 \mathrm{~h}$. Resorption pits on the slice were stained with Mayer's hematoxylin solution. Resorption was quantified on the number of pits. (B) Mouse long bones prelabeled with ${ }^{45} \mathrm{Ca}$ were cultured for $72 \mathrm{~h}$ with and without quercetin and in the presence of PTH $\left(10^{-7} \mathrm{M}\right)$. At the end of culture period, bones were extracted in $0.1 \mathrm{~N}$ $\mathrm{HCl}$. Bone-resorbing activity was expressed as the percentage of the incorporated ${ }^{45} \mathrm{Ca}$ that was released into the medium. Data are means \pm S.E. of results from three determinations. $*, p<0.01 v s$. control.

tion of osteoclasts. In this study we demonstrated that quercetin inhibits TRAP- $(+)$ pOC formation induced by sRANKL in cultures of MD and RAW cells, induces the disruption of actin rings in OCLs, and suppresses bone resorption in both pit assay and organ cultures. Our results indicate that the suppressive effect of quercetin on bone resorption might mainly result from its inhibitory effect on the early differentiation of osteoclast progenitor into pOC (Fig. 3) and its disruptive effect of actin rings in OCLs.

Onion extracts are known to prevent stimulated bone loss in animal experiments. ${ }^{9-11)}$ Recently it was demonstrated from OVX animal experiments that rutin is the main effective component of onion extract on bone resorption. ${ }^{12}$ However, its target cells related to bone resorption have not been determined. Quercetin, one of the main flavonoid components, inhibited TRAP- $(+)$ pOC formation from both MD and RAW cell culture. We demonstrated the effect of quercetin on the early differentiation of osteoclasts from osteoclast progenitor cells, suggesting that they are one of the target cells of quercetin, and that its inhibitory effect on early differentiation is partially responsible for its suppressive effect on bone resorption in organ culture.

Recently, Wattel et al. reported that quercetin induces apoptosis in mature osteoclasts and inhibits bone resorption. ${ }^{20)}$ Although the $\mathrm{IC}_{50}$ of quercetin on bone resorption is $5.3 \mu \mathrm{M}$, the $\mathrm{ED}_{50}$ (effective dose) of quercetin on apoptosis in osteoclasts was more than $50 \mu \mathrm{M}^{20}{ }^{20}$ Thus, the quercetin-induced stimulation of apoptosis could partly explain its inhibitory effect on bone resorption. ${ }^{20)}$ In our study, $12 \mathrm{~h}$ treatment of $10 \mu \mathrm{M}$ quercetin induced the disruption of actin rings (actin ring formation is an essential process in expressing bone resorption function) in OCLs by $80 \%$, but TRAP activity and the cell viability of OCLs decreased by less than $15 \%$. Furthermore, the removal of quercetin after $12 \mathrm{~h}$ treatment restored OCLs with actin rings by $80 \%$ of control cultures $(24 \mathrm{~h})$. These results indicated that quercetin-treated non-functional OCLs, where actin rings were disrupted, are still alive. The effective dose of quercetin for actin ring disruption was almost the same as that on bone resorption.
These facts suggest that quercetin's inhibitory effect on pit formation results mainly from its disruptive effect on actin rings, although quercetin-induced apoptosis in OCLs may be partially involved in the suppression of bone resorption in the pit assay. Taken together, the inhibitory effects of quercetin on the early differentiation of osteoclast progenitors into pOC and actin ring formations in mature osteoclasts may explain its suppressive effect on bone resorption in organ cultures. Our findings also provide an explanation for quercetin's preventive effect on postmenopausal osteoporosis.

RANKL and M-CSF are two essential factors for pOC formation. MD cells, M-CSF-dependent cells derived from mouse bone marrow cells, are able to proliferate in the presence of M-CSF. Quercetin did not affect the proliferation mediated by M-CSF in MD cell cultures. Simultaneous treatment of MD cells with M-CSF and sRANKL induced the formation of pOCs; however, Quercetin inhibited pOC formation induced by RANKL from both MD and RAW cells. These results suggest that the inhibitory effect of quercetin on pOC formation is involved in the RANKL-mediated signaling pathway in both cell cultures. Extracellular signalingregulated kinase (ERK) kinase (MEK), p38 mitogen-activated protein kinase (MAPK) c-Jun N-terminal kinase (JNK) and NF-kappa B activation are involved in the RANKL-signaling pathway for osteoclastogenesis. ${ }^{21-23)}$ There are also several signal-transducing molecules related to actin ring formation in osteoclasts: p60 $0^{\text {c-src }}$ tyrosine kinase, ${ }^{24,25)} \mathrm{PI} 3 \mathrm{~K},{ }^{26,27)}$ GTP-binding proteins, ${ }^{28,29)}$ and PKA. ${ }^{30)}$ Quercetin is known to inhibit the JNK pathway and protein tyrosine kinase. ${ }^{31-33)}$ These facts also suggest that quercetin may act on the signaling pathway involved in the formation of actin rings. Further study is necessary to better clarify the modes of action on both osteoclastogenesis and actin ring formation.

Quercetin, one of the most abundant flavonoids in the human diet, and its glucosides are present in high concentration in apples, broccoli, wine, and tea as well as in onions. ${ }^{34)}$ Quercetin is obtained from the daily intake of these foods. The plasma concentration of quercetin in human ranges from $0.5 \mu \mathrm{M}$ to $1.6 \mu \mathrm{M},{ }^{35)}$ correlats well with the concentrations that inhibit pOC formation. Thus, quercetin would be expected to inhibit bone resorption in human, and might be applicable for the prevention of bone diseases such as postmenopausal osteoporosis.

Acknowledgments This work was partly supported by Research Institute for Biological Function and by a Grant-inAid for Scientific Research on Priority Areas (B) (15380077) from the Ministry of Education, Culture, Sports, Science and Technology Japan.

\section{REFERENCES}

1) Suda T., Takahashi T., Martin T. J., Endocr. Rev., 13, 66-80 (1992).

2) Chambers T. J., J. Pathol., 192, 4-13 (2000).

3) Suda T., Takahashi N., Udagawa N., Jimi E., Gillespie M. T., Martin T. J., Endocr. Rev., 20, 345-357 (1999).

4) Yasuda H., Shima N., Nakagawa N., Yamaguchi K., Kinosaki M., Mochizuki S., Tomoyasu A., Yano K., Goto M., Murakami A., Tsuda E., Morinaga T., Higashio K., Udagawa N., Takahashi N., Suda T., Proc Natl. Acad. Sci. U.S.A., 95, 3597-3602 (1998).

5) Lancey D. L., Timms E., Tan H. L., Kelley M. J., Dunstan C. R., Burgess T., Elliott R., Colombero A., Elliott G., Scully S., Hsu H., 
Sullivan J., Hawkins N., Davy E., Capparelli C., Eli A., Qian Y. X., Kaufman S., Sarosi I., Shalhoub V., Senaldi G., Guo J., Delaney J., Boyle W. J., Cell, 93, 165-176 (1998).

6) Hsu H., Lacey D. L., Dunstan C. R., Solovyev I., Colombero A., Timms E., Tan H. L., Elliott G., Kelley M. J., Sarosi I., Wang L., Xia X. Z., Elliott R., Chiu L., Black T., Scully S., Capparelli C., Morony S., Shimamoto G., Bass M. B., Boyle W. J., Proc. Natl. Acad. Sci. U.S.A., 96, 3540-3545 (1999).

7) Muhlbauer R. C., Li F., Nature (London), 401, 343-344 (1999).

8) Li F., Muhlbauer R. C., J. Bone Miner. Res., 14, 1457-1465 (1999).

9) Wronski T. J., Walsh H., Ignaszewski L. A., Bone, 7, 119-123 (1986).

10) Cecchini M. G., Fleasch H., Muhlbauer R. C., Calcif. Tissue Int., 61, S9-S11 (1997).

11) Ingold P., Kneissel M., Muhlbauer R. C., Gasser J. A., Bone, 23 (Suppl.), S387 (1998).

12) Horcajada-Molteni M. N., Crespy V., Coxam V., Davicco M. J., Remesy C., Barlet J. P., J. Bone Miner. Res., 15, 2251-2258 (2000).

13) Hertog M. G., Hollman P. C. H., Katan M. B., Kromhout D., Nutr. Cancer, 20, 21-29 (1993).

14) Price K. R., Rhodes M. J. C., J. Sci. Food Agric., 74, 331-339 (1997).

15) Tamura G., Gold C., Fezz-Luzi A., Ames B. N., Proc. Natl. Acad. Sci. U.S.A., 77, 4961-4965 (1980).

16) Wani M. R., Fuller K., Kim N. S., Choi Y., Chambers T., Endocrinology, 140, 1927-1935 (1999).

17) Takahashi N., Akatsu T., Udagawa N., Sasaki T., Yamaguchi A., Moseley J. M., Martin T. J., Suda T., Endocrinology, 123, 2600-2602 (1988).

18) Hotokezaka H., Sakai E., Kanaoka K., Saito K., Matsuo K., Kitaura H., Yoshida N., Nakayama K., J. Biol. Chem., 277, 47366-47372 (2002).

19) Tamura T., Takahashi N., Akatsu T., Sasaki T., Udagawa N., Tanaka S., Suda T., J. Bone Miner. Res., 8, 953-960 (1993).

20) Wattel A., Kamel S., Mentaverri R., Lorget F., Prouillet C., Petit J. P., Fardelonne P., Brazier M., Biochem. Pharmacol., 65, 35-42 (2003).

21) Matsumoto M., Sudo T., Saito T., Osada H., Tsujimoto M., J. Biol.
Chem., 275, 31155-31161 (2000).

22) Lee S. E., Woo K. M., Kim S. Y., Kim H. M., Kwack K., Lee Z. H., Kim H. H., Bone, 30, 71-77 (2002).

23) Hotokezaka H., Sakai E., Kanaoka K., Saito K., Matsuo K. I., Kitaura H., Yoshida N., Nakayama K., J. Biol. Chem., 277, 47366-47372 (2002).

24) Yoneda T., Lowe C., Lee C. H., Gutierrez G., Niewolna M., Williams P. J., Izbicka E., Uehara Y., Mundy G. R., J. Clin. Invest., 91, 27912795 (1993).

25) Hall T. J., Schaeublin M., Missbach M., Biochem. Biophys. Res. Commun., 199, 1237-1244 (1994).

26) Nakamura I., Sasaki T., Tanaka S., Takahashi N., Jimi E., Kurokawa T., Kita Y., Ihara S., Suda T., Fukui Y., J. Cell Physiol., 172, 230-239 (1997).

27) Nakamura I., Takahashi N., Sasaki T., Tanaka S., Udagawa N., Murakami H., Kimura K., Kabuyama Y., Kurokawa T., Suda T., Fukui Y., FEBS Lett., 361, 79-84 (1995).

28) Zhang D., Udagawa N., Nakamura I., Murakami H., Saito S., Yamasaki K., Shibasaki Y., Morii N., Narumiya S., Takahashi N., Suda T., J. Cell Sci., 108, 2285-2292 (1995).

29) Chellaiah M. A., Soga N., Swanson S., McAllister S., Alvarez U., Wang D., Dowdy S. F., Hruska K. A., J. Biol. Chem., 275, 11993$12002(2000)$.

30) Suzuki H., Nakamura I., Takahashi N., Ikuhara T., Matsuzaki K., Isogai Y., Hori M., Suda T., Endocrinology, 137, 4685- 4690 (1996).

31) Jacquemin-Sablon A., Agbotounou W. K., Pierre J., Pathol. Biol. (Paris), 43, 389-394 (1995).

32) Kobuchi H., Roy S., Sen C. K., Nguyen H. G., Packer L., Am. J. Physiol., 277, C403-C411 (1999).

33) Yoshizumi M., Tsuchiya K., Suzaki Y., Kirima K., Kyaw M., Moon J. H., Terao J., Tamaki T., Biochem. Biophys. Res. Commun., 293, 1458-1465 (2002).

34) Manach C., Morand C., Crespy V., Demigne C., Texier O., Regerat F., Remesy C., FEBS Lett., 426, 331-336 (1998).

35) Paganga G., Rice-Evans C. A., FEBS Lett., 401, 78-82 (1997). 